\title{
Isolation, Characterization, and Pharmaceutical Applications of an Exopolysaccharide from Aerococcus Uriaeequi
}

\author{
Chunlei Wang ${ }^{1}$, Qiuping Fan ${ }^{1}$, Xiaofei Zhang ${ }^{1}$, Xiaoping Lu ${ }^{1}$, Yanrui Xu ${ }^{1}$, Wenxing Zhu ${ }^{1}$, \\ Jie Zhang ${ }^{1}$, Wen Hao ${ }^{2,3}$ and Lujiang Hao ${ }^{1, *}$ \\ 1 State Key Laboratory of Biobased Material and Green Papermaking, Qilu University of Technology, \\ Shandong Academy of Sciences, Jinan 250353, China; chunlei_wang79@163.com (C.W.); \\ fanqiuping1990@163.com (Q.F.); xiaofei_305@163.com (X.Z.); 15269213716@163.com (X.L.); \\ 15269211209@163.com (Y.X.); zhwenxing@163.com (W.Z.); zhangjie@qlu.edu.cn (Z.J.) \\ 2 Qingdao Municipal Center for Disease Control \& Prevention, Qingdao 266033, China; cdchaowen@126.com \\ 3 Qingdao Institute of Preventive Medicine, Qingdao 266033, China \\ * Correspondence: lujiang_hao@qlu.edu.cn
}

Received: 28 August 2018; Accepted: 13 September 2018; Published: 16 September 2018

\begin{abstract}
Many marine bacteria secrete exopolysaccharides (EPSs), which are made up of a substantial component of the macro-molecules surrounding cells. Recently, the wide demand for EPSs for food, cosmetics, pharmaceutical and other applications has led to great interest in them. In this study, an EPS produced by marine bacteria Aerococcus uriaeequi HZ strains (EPS-A) was isolated and purified to examine its structure and biological function. The molecular weight of EPS-A analyzed by high-performance liquid gel filtration chromatography (HPGFC) is found to have a number average of $2.22 \times 10^{5}$ and weight average of $2.84 \times 10^{5}$, respectively. High-performance liquid chromatography (HPLC) and Fourier-transform-infrared (FT-IR) analysis indicate that EPS-A was a polysaccharide composed of glucose and a little mannose. In addition, the flocculating rate of sewage of EPS-A was 79.90\%. The hygroscopicity studies showed that hygroscopicity of EPS-A was higher than chitosan but lower than that of sodium hyaluronate. The moisture retention of EPS-A showed similar retention activity to both chitosan and sodium hyaluronate. EPS-A also can scavenge free radicals including both $\mathrm{OH} \bullet$ free radical and $\mathrm{O}_{2} \bullet-$ free radical and the activity to $\mathrm{O}_{2} \bullet-$ free radical is similar to vitamin C. Safety assessment on mice indicated that the EPS-A is safe for external use and oral administration. EPS-A has great potential for applications in medicine due to its characteristics mentioned above.
\end{abstract}

Keywords: marine bacteria; EPS-A; structural analysis; sewage flocculation; oxidation resistance

\section{Introduction}

Microbial exopolysaccharides are critical for the biofilm formation, which is involved in the protection of bacteria against a harmful environment and in the adherence. The EPS layers with high viscosity are formed by accumulating various types of polymeric substances. They tend to be hygroscopic and aerophytic bacteria, and often contain more water than the surrounding environment [1]. It is known that certain marine bacterial polysaccharides have features such as hygroscopicity and moisture resistance, ability to scavenge free radicals, oxidation resistance, and the adsorption of heavy metal ions. The EPS from Pseudoalteromonas SM20310 enables the strain to adapt to the environments such as low temperature, high salt concentration, and freeze-thaw cycles. In addition to its functions in the strain, the EPS also obviously increased the tolerance of Escherichia coli to repeated freeze-thaw cycles [2]. Many studies indicate that the biological activities of polysaccharides 
are related to their structural features, including molecular weight and concentration, the compositions of sugar, branch structures, and type of glycosyl linkage [3].

Polysaccharides and their derivatives have been widely used in industries, such as food process, pharmaceutics, cosmetic, and health care. For instance, polysaccharides extracted from algae have been applied as the excipients in cosmetic formulae because of their high bonding, gelling, and viscosity-increasing properties [4]. Moreover, the polysaccharide from Morchella conica (Fungi, Ascomycota) may act as a powerful immunomodulatory agent by modulating nitric oxide production in macrophages and subserve splenocytes proliferation [5]. EPSs can be readily prepared in the laboratory by fermentation [6]. Previous experiments proved that the yield of EPS from the submerged fermentation of Chinese truffle Tuber sinense (Fungi, Ascomycota) can reach $1.59 \mathrm{~g} / \mathrm{L}$ under predicted optimal conditions [7]. Pseudoalteromonas SM20310 (Bacteria, Proteobacteria) screened from 110 Arctic sea ice can produce EPS with of $0.57 \mathrm{~g} / \mathrm{L}$ [2]. The bacterial strain CAM025 from Pseudoalteromonas isolated from Antarctic yield ca $100 \mathrm{mg}$ EPS per gram dry weight of cells of EPS at $-2{ }^{\circ} \mathrm{C}$ and at $10{ }^{\circ} \mathrm{C}[8]$.

In this study, a marine bacterium Aerococcus uriaeequi $\mathrm{HZ}$ with the production of EPSs was screened from abalone aquaculture environments. In order to study the production of the EPSs produced by A. uriaeequi $\mathrm{HZ}$, the strain was cultured and an EPS was extracted, isolated, and purified (names EPS-A). We also analyze the structure and composition of EPS-A by Fourier-transform-infrared (FT-IR) spectrometry and high-performance gel filtration chromatography (HPGFC). Finally, its flocculation properties, moisture-absorption and retention abilities and antioxidant activity were studied to explore its potential application in biotechnology.

\section{Results}

\subsection{Extraction and Purification of Microbial Exopolysaccharide (EPS-A)}

EPSs from bacteria have been widely used as anticoagulant, antithrombotic, immunomodulation, anticancer agents and as bioflocculants in areas such as pharmacological, nutraceutical, functional food, cosmeceutical and herbicides [9]. Many marine bacteria secrete EPSs as a strategy for growth, adherence, and to survive under harmful conditions [10]. A. uriaeequi $\mathrm{HZ}$ strain was isolated from the Yellow Sea of China. To analyze if the bacteria can produce EPSs, A. uriaeequi was fermented and the EPS-A was isolated by Diethylaminoethano (DEAE) ion exchange chromatography and gel filtration chromatography. The freeze-dried product was yellow-white, water-soluble powder. HPGFC results showed that the purified product forms a single and symmetric peak, which indicated that EPS-A was purified with high quality. In order to avoid the presence of protein on the production of extracellular polysaccharides, the products were scanned by a ultraviolet (UV)-visible spectrophotometer. EPS-A did not show absorption at $260 \mathrm{~nm}$ and $280 \mathrm{~nm}$ in the UV spectrum (Figure 1B), which suggested that the nucleic acid and protein was in the absence [11], and the total sugar content of the EPS is ca $2.34 \mathrm{~g} / \mathrm{L}$. The molecular weight of EPS-A was further measured by HPGFC, and the molecular distribution of HPGPC of EPS-A is shown in Figure 1A. The result showed that EPS-A is the sugar with the number average $2.22 \times 10^{5}$ and weight average $2.84 \times 10^{5}$, respectively. The distribution coefficient was 1.28, indicating the small coefficient dispersion of EPS-A (Table 1).

Table 1. The yield and molecular weight distribution of microbial exopolysaccharide (EPS-A).

\begin{tabular}{cccc}
\hline $\begin{array}{c}\text { Total Sugar Content } \\
(\mathrm{g} / \mathrm{L})\end{array}$ & $\begin{array}{c}\text { Number Average } \\
\text { Molecular Mass (g/mol) }\end{array}$ & $\begin{array}{c}\text { Weight Average } \\
\text { Molecular Mass (g/mol) }\end{array}$ & Distribution Coefficient \\
\hline 2.34 & $2.22 \times 10^{5}$ & $2.84 \times 10^{5}$ & 1.28 \\
\hline
\end{tabular}


A

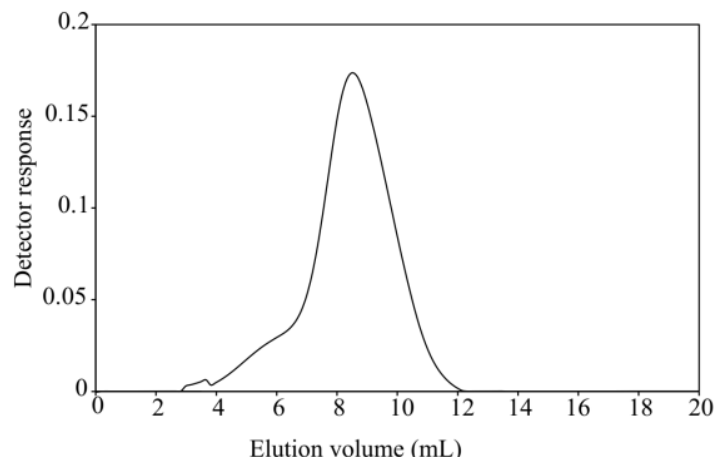

B

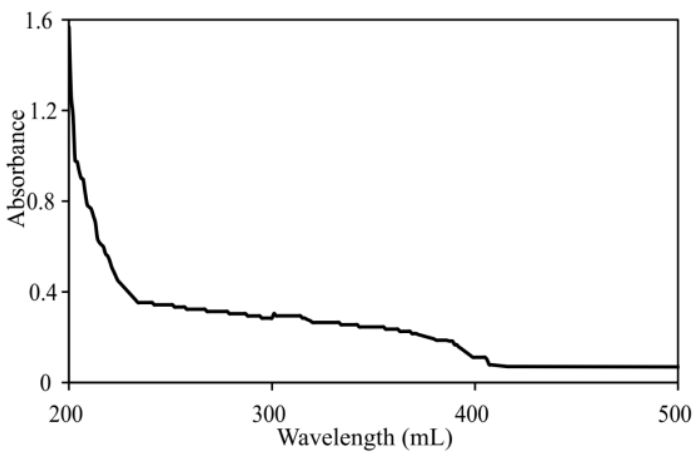

Figure 1. Purification of EPS-A. (A) Mw distribution of EPS-A determination by high-performance liquid gel permeation chromatography (HPGFC). HPGFC was performed using a Shodex SB-806HQ column in $0.2 \mathrm{M} \mathrm{NaCl}$ solution with $0.5 \mathrm{~mL} / \mathrm{min}$ flow rate. (B) Ultraviolet (UV)-visible spectrum of EPS-A. The absorbance from $200-500 \mathrm{~nm}$ was measured in $\mathrm{H}_{2} \mathrm{O}$ at room temperature.

\subsection{Monosaccharide Composition Analysis of EPS-A}

Monosaccharide composition analysis is used to determine the identities and quantities of the various monosaccharides in the carbohydrates and glycoproteins. The information can be used to analyze the structure of carbohydrates and play an important role in quantification. The monosaccharide composition of EPS-A was identified by high-performance liquid chromatography (HPLC). EPS-A was hydrolyzed by sulfuric acid and derivatized with 1-phenyl-3-methyl-5-pyrazolone (PMP). As shown in Figure 2, two kinds of monosaccharide were found, D-mannose and D-glucose, accounting for $10.71 \%$ and $66.99 \%$, respectively. As compared with PMP-labeled standard monosaccharides (Figure 2A), the molar ratio of D-mannose and D-glucose of EPS-A was 1:9.65 (Figure 2B). This result was different from an exopolysaccharide produced by Bifidobacterium animalis with $\mathrm{Mw}=21.3 \mathrm{kDa}$, which was composed of the monosaccharides including arabinose, galactose, glucose, mannose, and rhamnose [12].

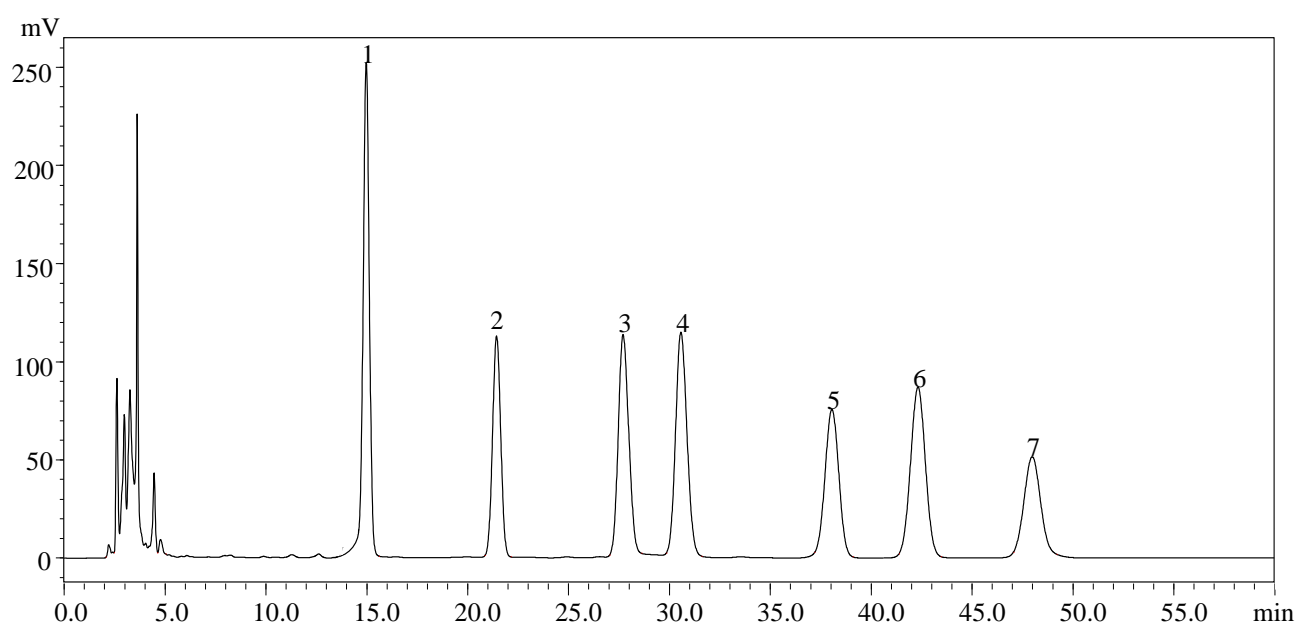

(A)

Figure 2. Cont. 


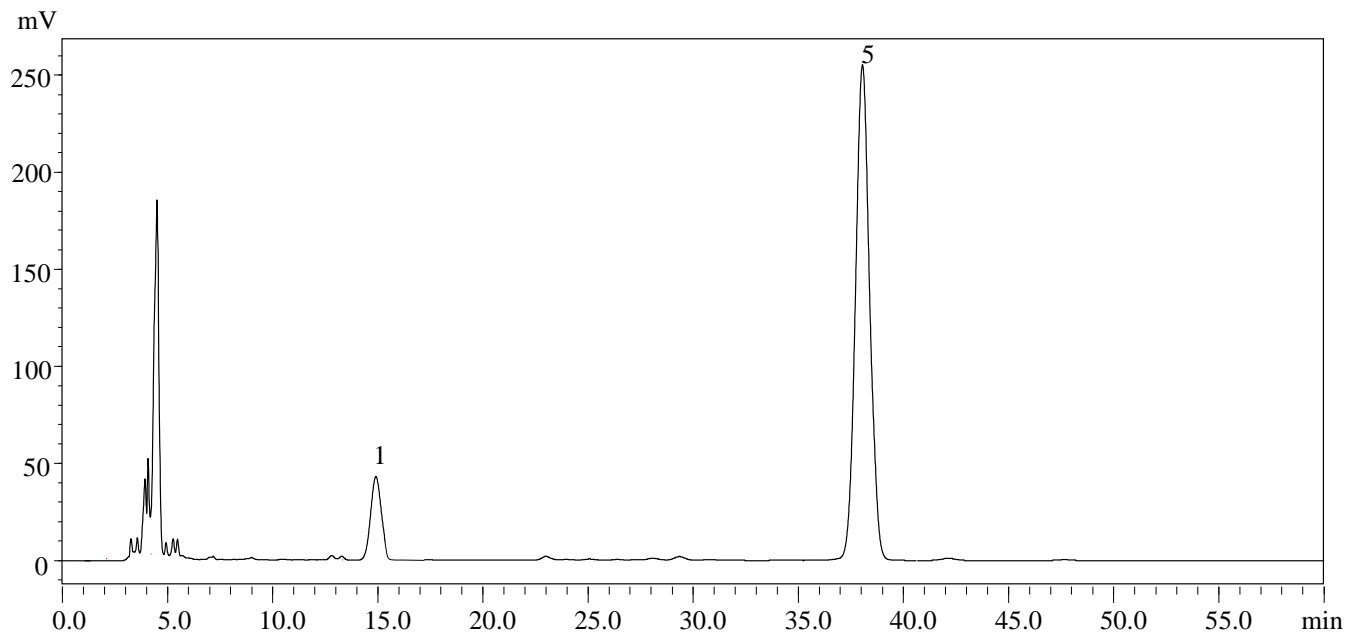

(B)

Figure 2. High-performance liquid chromatography (HPLC) chromatograms of seven PMP-labeled standard monosaccharides (A) and PMP-labeled monosaccharides released from EPS-A (B). Peaks:

1. D-Mannose; 2. D-Rhamnose; 3. D-Glucuronic acid; 4. D-Galacturonic acid; 5. D-Glucose;

6. D-Galactose;7. d-Xylose.

\subsection{Fourier-Transform-Infrared (FT-IR) Analysis}

FT-IR spectroscopy is a widely used method that shows the infra-red-light absorption by molecular bonds at a given wavelength [13]. The method can analyze the polysaccharide structure, such as monosaccharide types, glucosidic bonds, and functional groups, by investigating the vibrations of molecules and polar bonds between atoms [14-16].

EPS-A had polysaccharide characteristic of a broad absorption peak in $3200 \sim 3650 \mathrm{~cm}^{-1}$, which was the $\mathrm{O}-\mathrm{H}$ stretching vibration peak (Figure 3). The peak at $2887.4 \mathrm{~cm}^{-1}$ and $2935.6 \mathrm{~cm}^{-1}$ were $-\mathrm{C}-\mathrm{H}$ stretching vibration of $-\mathrm{CH}_{3}$ and $-\mathrm{CH}_{2}$, respectively. Around $1100 \mathrm{~cm}^{-1}$, there are three absorption peaks, indicating the presence of monosaccharides in pyran form in the extracellular polysaccharide. The characteristic absorption peak at $817 \mathrm{~cm}^{-1}$ confirmed the presence of $\alpha$-D-mannopyranose $[17,18]$. The structure of the infrared spectrometry confirmed the measurement results of the monosaccharide composition.

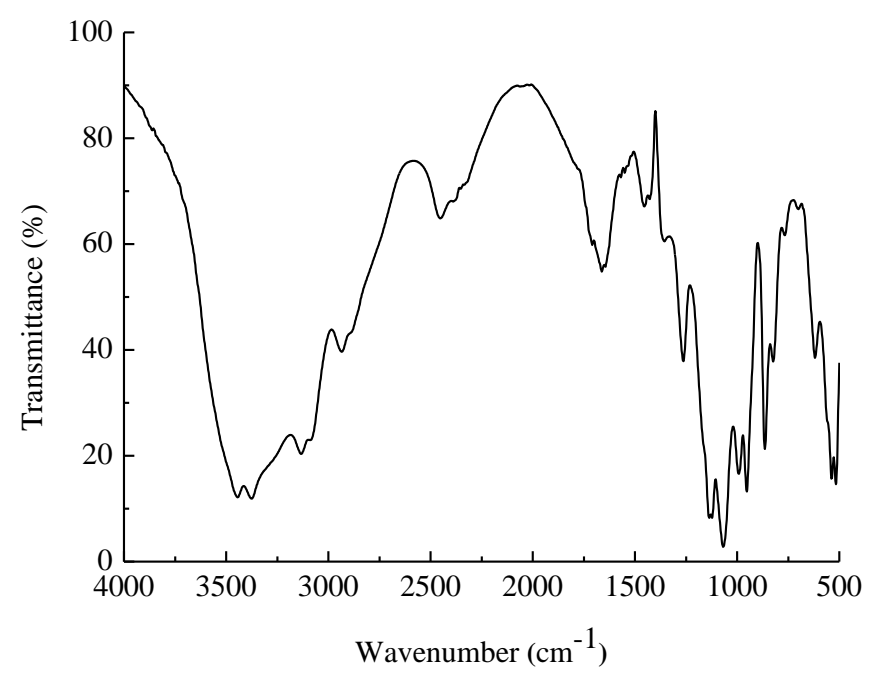

Figure 3. FT-IR spectra of EPS-A. Dried polysaccharides were ground and pelletized with $\mathrm{KBr}$. Ultraviolet-visible spectrum of EPS-A was recorded with a spectrophotometer from $500-4000 \mathrm{~cm}$. 


\subsection{Bio-Flocculating Activity}

Flocculation technology as a kind of effective and quick method is used for wastewater treatment. Bio-flocculation is a dynamic process owing to the ability to form extracellular polymers by living cells. Recently, microbial flocculants have been widely used, which are innocuous and biodegradable. The flocculating activity of an EPS by Bacillus thuringiensis is $80.4 \%$ [19]. An EPS produced by a marine dinoflagellate Gyrodinium impudicum (Chromista, Dinophyceae) had $>90 \%$ flocculating activity [20]. In this study, the flocculating rate was as high as $79.90 \%$ (Figure 4), With the increase of concentration, the flocculation ability of EPS-A gradually increased. The results show that EPS-A could be an excellent candidate as a kind of sewage treatment agent that is non-toxic, harmless, no secondary pollution.

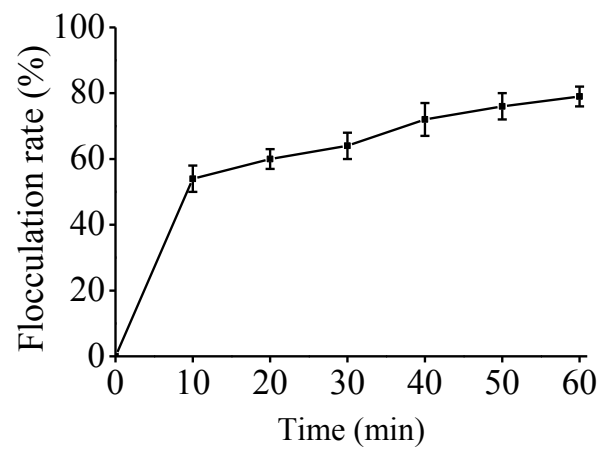

Figure 4. Sewage flocculation assay of EPS-A. 0.2 g EPS was added $100 \mathrm{~mL}$ sewage and incubated for $1 \mathrm{~h}$. The function of sewage flocculation was measured at $550 \mathrm{~nm}$ by a spectrophotometer.

\subsection{Moisture Absorption and Retention Properties EPS-A}

EPSs are hygroscopic and therefore have the ability to maintain a high water content in the microenvironment [21]. The hygroscopic property has been widely used in the food industry [22]. The hygroscopicity of EPS-A was investigated together with chitosan and sodium hyaluronate. The experimental results showed that EPS-A moisture absorption was significantly higher than that of chitosan but less than that of sodium hyaluronate.

The moisture retention ability of EPSs plays an important role in cosmetics and clinical medicine [23]. The moisture retention of EPS-A was studied and compared with that of chitosan and sodium hyaluronate. The results showed EPS-A has similar moisture-absorption abilities as that of chitosan and sodium hyaluronate (Figure 5). The moisture absorption and retention properties make EPS-A valuable in the food industry, clinical medicine, and cosmetics.

A

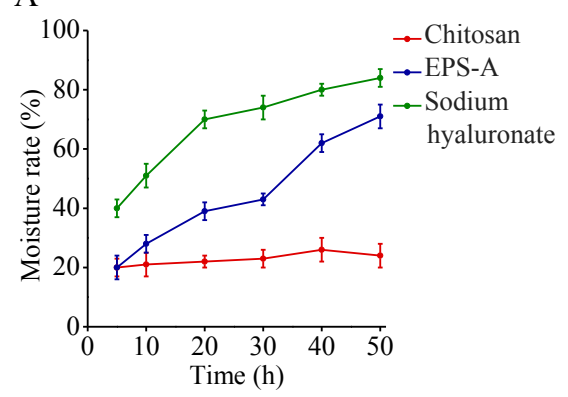

B

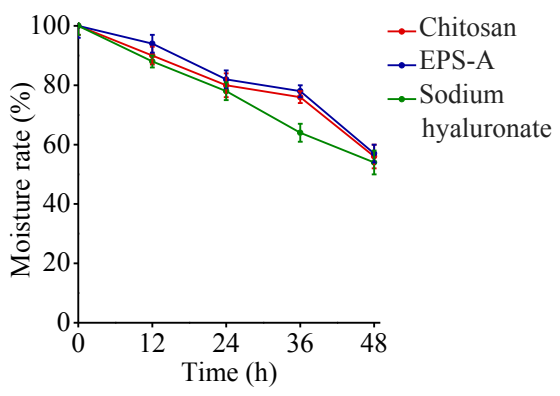

Figure 5. Moisture-absorption and retention activity of EPS-A. (A) Hygroscopic activity assay of EPS-A. Hygroscopic activity of EPS-A was determined by measuring the increased weight of absorbing $\mathrm{H}_{2} \mathrm{O}$ by EPS-A. Chitosan and sodium hyaluronate were used as controls. The value obtained at $50 \mathrm{~h}$ by sodium hyaluronate was set $100 \%$. (B) Moisture retention activity assay of EPS-A. Moisture retention of EPS-A was determined by measuring the reserved weight of $\mathrm{H}_{2} \mathrm{O}$ by EPS-A. Chitosan and sodium hyaluronate were used as controls. And the value at the beginning was set $100 \%$. 


\subsection{Removal Results on Free Radicals}

The oxygen free radicals such as superoxide radical anion $\left(\mathrm{O}_{2} \bullet^{-}\right)$and hydroxyl radical $(\mathrm{OH} \bullet)$ are highly potent oxidants that can react with the biomacromolecules in cells and are related to mutagenesis and carcinogenesis. The antioxidant properties of polysaccharides from algae, plant, fungi, and prokaryotes have been studied for their antioxidant properties as potential therapeutic [24]. For example, Dixoniella grisea (formerly Rhodella reticulata, Rhodophyta) EPS had a stronger ability against $\mathrm{O}_{2} \bullet-$ than $\alpha$-tocopherol and the crude polysaccharides were twice as strong as $\alpha$-tocopherol [25]. Natural EPS from Brevibacterium otitidis (Bacteria, Actinobacteria) also possessed a strong free radicals scavenging effect, which can be comparable to vitamin $\mathrm{C}$ [26]. In this study, $\mathrm{OH} \bullet$ free radical and super oxygen anion $\mathrm{O}_{2} \bullet-$ scavenging activity of EPS-A were analyzed (Figure 6). The results showed that the scavenging effect of EPS-A on $\mathrm{OH} \bullet$ radicals increased with increasing concentration of EPS-A. when EPS-A concentration reached $100 \mu \mathrm{g} / \mathrm{mL}$, the clearance rate reached $45.65 \%$, which is lower than the value of Vitamin $\mathrm{C}(\mathrm{Vc})$. Scavenging results of EPS-A on $\mathrm{O}_{2} \bullet{ }^{-}$also showed a significant dose-effect relationship. When the concentration of EPS-A reached $250 \mu \mathrm{g} / \mathrm{mL}$, the clearance rate was $67.31 \%$, which is near to Vc. EPS-A showed similar clearance rate to both superoxide radical anion and hydroxyl radical, even the rate is lower than Vc. Then EPS-A may also be explored as a novel potential antioxidant. The hydroxyl radical scavenging activities of EPSs were attributed to various mechanisms. One possibility was that EPSs could absorb radicals and terminate the radical reaction [27].

A

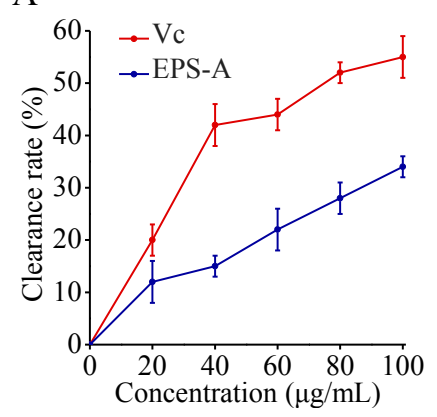

B

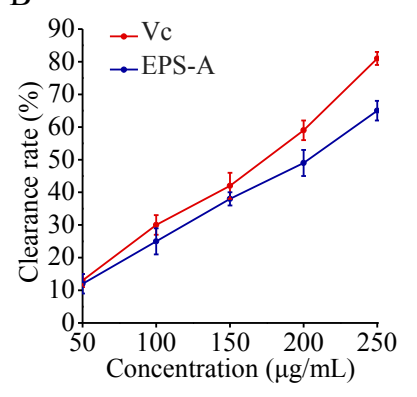

Figure 6. Free radical scavenging activity of EPS-A. A OH• free radical scavenging activity of EPS-A. The scavenging activity to $\mathrm{OH} \bullet$ of different concentration EPS was determined by removing $\mathrm{OH} \bullet$ generated by $\mathrm{FeSO}_{4}$ and $\mathrm{H}_{2} \mathrm{O}_{2}$. Vitamin $\mathrm{C}$ was used as a control and the activity of $100 \mu \mathrm{g} / \mathrm{mL}$ vitamin C was set $100 \%$. $\mathbf{B ~ O}_{2} \bullet^{-}$free radical scavenging activity of EPS-A. The scavenging activity to $\mathrm{O}_{2} \bullet^{-}$of different concentration EPS-A was determined by removing $\mathrm{O}_{2} \bullet^{-}$generated from pyrogallol. Vitamin $\mathrm{C}$ was used as a control and the activity of $100 \mu \mathrm{g} / \mathrm{mL}$ Vitamin C was set $100 \%$.

\subsection{Safety Assessment of EPS-A}

An acute toxicity test on mice was performed to assess the safety of the EPS-A. The mice were orally administered a dose of $5000 \mathrm{mg} / \mathrm{kg}$ of the EPS-A. No mice died in either the treated or the control group in the 14-day test period. In both groups, the mean body weight of mice increased gradually and did not show a significant difference during growth, and at the end of the test (Figure 7A). there was also no substantial difference of the splenic indices between treated mice and the untreated controls (Figure 7B). The acute toxicity test indicated that EPS-A is safe for usage. 

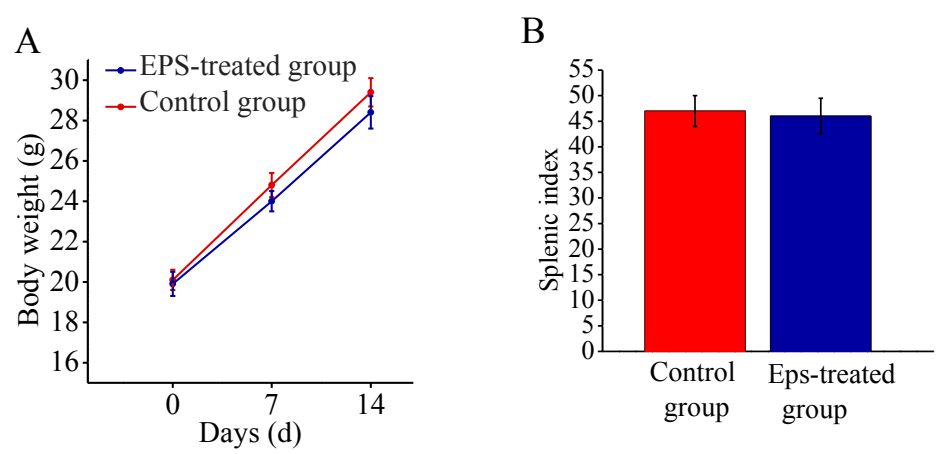

Figure 7. Effect of EPS-A on the body weight (A) and splenic indices (B) of mice in a 14-day feeding test.

\section{Discussion}

Microbial EPSs have attracted great interest among scientists because of their wide potential applications spanning areas such as health (pharmaceuticals and medicine), industry (cosmetics, textile, dairy etc.), and environment (flocculation, remediation, etc.) [28]. However, only a few microbial EPSs have been used commercially. Among them, microbial dextran could be considered as the first example used in food and pharmaceutical industries [24]. Their production costs are the main constraints to full commercialization, especially the substrate cost and the cost of purification processing [29]. EPSs are of considerable value in the removal of pollutants from wastewater, in the dewatering of activated sludge, and in bioflocculation and settling [30]. Flocculation activity $>75 \%$ was obtained using very low concentrations of EPSs from Bacillus, and our results showed that EPS-A showed activity of $79.90 \%$.

In this study, EPS-A showed good moisture-absorption and retention ability. The moistureabsorption ability of EPS-A was between chitosan and sodium hyaluronate; and its moisture-retention ability was comparable with chitosan and sodium hyaluronate. Similarly, Sun et al. [31] found the moisture-absorption ability of extracellular polysaccharide produced by an Arctic marine bacteria was higher than that of chitosan but less than that of sodium hyaluronate. Moreover, the moisture-retention ability was higher than that of chitosan and sodium alginate. To my knowledge, few studies are able to clarify this mechanism of extracellular polysaccharides. Chen's group [32] reported that the moisture-absorption and retention ability of Carboxymethyl chitosans (CM-chitosan) containing different subrogation points was related to the active sites of 6-carboxymethyl in the molecular structure. Moreover, the carboxymethylation of $\mathrm{N}$ sites promote moisture-absorption and retention ability which increase with its molecular weight. The extracellular polysaccharides of the Arctic marine bacteria are mainly composed of $\mathrm{N}$-acetyl glucosamine, glucuronic acid, mannose, medium galactose, and fucose, as well as a small amount of rhamnose and glucose. In this study, the EPS-A is proved to consist of glucose and a small amount of mannose. It is speculated that the monosaccharide composition of the bacterial extracellular polysaccharide and the molecular weight of the extracellular polysaccharide have a great relationship with the moisture-absorption and retention ability, and the mechanism of the difference in moisture-absorption and retention ability need to be revealed in the later period. In addition, moisture-retaining and absorbing bio-materials have been extensively used in cosmetic, food, pharmaceutical and other industries [31]. The moisture-retention ability of EPS-A reveals its great potential as a wound dressing and moisturizing ingredient [33]. Also, EPS-A showed its antioxidant activity as Vc. The antioxidant properties of EPSs are important functions in maintaining human health and preventing disease. For example, an EPS from Pleurotus salmoneo-stramineus (Fungi, Basidiomycota) with antioxidant activity represented a surprising antitumor capability against colon cancer [34]. In summary, our study showed that EPS-A is a promising biomaterial for food, cosmetics and medical applications (Figure 8). 


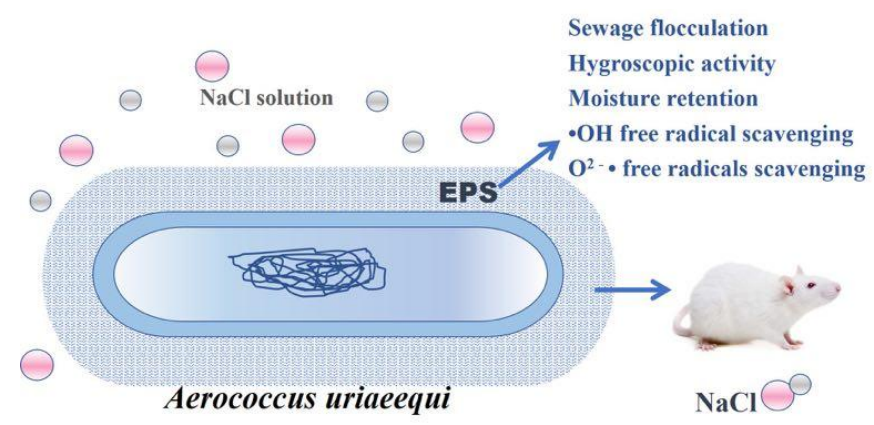

Figure 8. Schematic diagram of EPS-A with the potential advantages (e.g., Sewage flocculation, Hygroscopic activity, Moisture retention, $\bullet \mathrm{OH}$ free radical scavenging, $\mathrm{O}^{2-} \bullet$ free radicals scavenging). The safety assessment will be performed on mice.

\section{Materials and Methods}

\subsection{Cell Culture}

Marine bacterium A. uriaeequi $\mathrm{HZ}$ [35] strain was isolated from abalone breeding environment in Rongcheng, Shandong Province, China, and cultivated on Zobell 2216E solid medium containing $5.0 \mathrm{~g} / \mathrm{L}$ peptone, $1.0 \mathrm{~g} / \mathrm{L}$ yeast extract, $0.01 \mathrm{~g} / \mathrm{L}$ sodium phosphate, and $35 \mathrm{~g} / \mathrm{L}$ bay salt with $\mathrm{pH}$ 7.6 7.8 at $25^{\circ} \mathrm{C}$. The medium with $30 \mathrm{~g} / \mathrm{L}$ sucrose, $2.5 \mathrm{~g} / \mathrm{L}$ beef extract, $30 \mathrm{~g} / \mathrm{L}$ bay salt, and $0.01 \mathrm{~g} / \mathrm{L}$ sodium phosphate was used for fermentation study to produce EPS-A.

\subsection{Production and Purification of EPS-A}

A. uriaeequi $\mathrm{HZ}$ was cultured in the flask at $25{ }^{\circ} \mathrm{C}$ for $8 \mathrm{~h}$, then $10 \%$ seed culture was inoculated in fermentation flasks and incubated on a shaker with $230 \mathrm{rpm}$ at $25^{\circ} \mathrm{C}$ for $35 \mathrm{~h}$. The fermentation broth was centrifuged at $4000 \mathrm{rpm}$ for $20 \mathrm{~min}$. Ethanol was added to the supernatants to reach the final concentration of $60 \%(\mathrm{v} / \mathrm{v})$ and precipitated overnight at $4{ }^{\circ} \mathrm{C}$ [36]. The precipitates were centrifuged at $4000 \mathrm{rpm}$ for $20 \mathrm{~min}$ to remove the supernatants. The pellets were dissolved in water and mixed with Savage reagent (chloroform: $n$-butanol $=5: 1$ ) at a 1:4 volume ratio. The solution was mixed sufficiently and centrifuged to remove organic solvents and denatured protein [37]. The total sugar content of the EPS was determined by the phenol-sulfuric acid method [35].

The EPS in deionized water was further purified by using DEAE-52 anion-exchange chromatography with a $1.6 \mathrm{~cm} \times 30 \mathrm{~cm}$ column. The samples were eluted at a flow rate of $60 \mathrm{~mL} / \mathrm{h}$ with a linear gradient of 0 to $1 \mathrm{M} \mathrm{NaCl}$ solution in the system. The EPS fraction was further purified using gel filtration chromatography (Sepharose 4B) on a column $(1.6 \mathrm{~cm} \times 100 \mathrm{~cm})$, which was eluted at a flow rate of $12 \mathrm{~mL} / \mathrm{h}$ with $0.1 \mathrm{M} \mathrm{NaCl}$ solution [2]. Then the purified EPS was dialyzed by deionized water using a selective semi-permeable membrane (8000 14,400 da). The polysaccharide was freeze-dried and stored at $4{ }^{\circ} \mathrm{C}$ until analysis [38].

\subsection{Molecular Weight Determination of EPS-A}

The molecular weight of EPS-A was determined by gel filtration chromatography [39]. HPGFC was used for analysis using a Shodex SB-806HQ column $(0.8 \mathrm{~cm} \times 30 \mathrm{~cm}$, Agilent, Santa Clara, $\mathrm{CA}, \mathrm{USA}$ ). The mobile phase included $0.2 \mathrm{M} \mathrm{NaCl}$ in $\mathrm{H}_{2} \mathrm{O}$. The system was run at a flow rate of $0.5 \mathrm{~mL} / \mathrm{min}$ at $35^{\circ} \mathrm{C} .100 \mu \mathrm{L}$ standard sample (Table 2) was injected into the liquid chromatograph. The chromatogram was recorded, and the universal correction and the linear regression equation was performed and calculated by Gel Permeation Chromatography (GPC) software (A.02.01, Agilent, Santa Clara, CA, USA). The EPS-A was determined in the same method as above. The standard curve was shown in Figure 9. The $\mathrm{k}$ value of the reference substance was 0.0006 , and the $\alpha$ value was 0.75 . The molecular weight and molecular weight distribution of EPS-A were calculated by GPC software. 
Table 2. Standard samples of the Polystyrene sulfate (PSS).

\begin{tabular}{ccc}
\hline Standard Samples LOT & MW (g/mol) & Weight (mg) \\
\hline PSS929n & 63,900 & 10.1 \\
PSS8065n & 152,000 & 10.2 \\
PSS13092 & 282,000 & 10.1 \\
PSS14052 & 976,000 & 10.0 \\
PSS9304-4 & $2,260,000$ & 10.0 \\
\hline
\end{tabular}

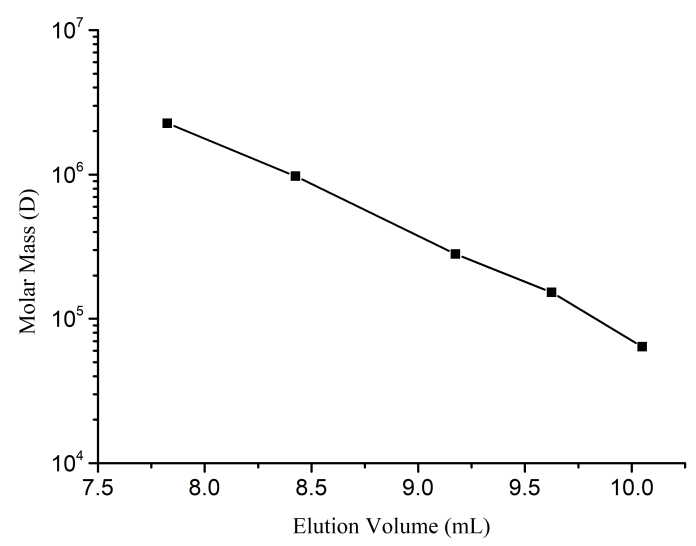

Figure 9. Standard curve of HPGPC-PSS series of standard samples.

\subsection{Hydrolysis and Derivatization of EPS-A}

Twenty mg EPS-A was mixed with the $10 \mathrm{~mL}$ sulfuric acid solution $(1 \mathrm{Mol} / \mathrm{L})$ and incubated at $100{ }^{\circ} \mathrm{C}$ for $8 \mathrm{~h}$ for hydrolysis. After centrifugation, the hydrolysate at $10,000 \mathrm{r} / \mathrm{min}$ for $10 \mathrm{~min}, 4.5 \mathrm{~mL}$ of supernatant was pipetted and neutralized to $\mathrm{pH} 7$ with $2 \mathrm{~mol} / \mathrm{L} \mathrm{NaOH}$, and the neutralized solution was made up to $10 \mathrm{~mL}$. PMP derivatization of monosaccharides was carried out as described previously with proper modification [40,41]. Briefly, $50 \mu \mathrm{L}$ neutralized solution, $50 \mu \mathrm{L}$ PMP-methanol solution $(0.5 \mathrm{~mol} / \mathrm{L})$ and $50 \mu \mathrm{L} \mathrm{NaOH}$ solution $(0.3 \mathrm{~mol} / \mathrm{L})$ were mixed in a $1.5 \mathrm{~mL}$ tube, which was placed in a constant temperature water bath at $70{ }^{\circ} \mathrm{C}$ for $30 \mathrm{~min}$. After cooling to room temperature, $50 \mu \mathrm{L}$ of $\mathrm{HCl}$ solution was added to the mixture for neutralization, and $100 \mu \mathrm{L}$ of ultrapure water was added for dilution. The mixture was extracted 3 times with chloroform, and filtered by a 0.45 -micron filter before HPLC. The $2 \mathrm{mmol} / \mathrm{L}$ standard solution of mannose, rhamnose, glucuronic acid, galacturonic acid glucose, galactose, and xylose was derivatized by the same method. All the assays were independently conducted in triplicate.

\subsection{High-Performance Liquid Chromatography (HPLC) Analysis of the Monosaccharide Composition}

An HPLC (DGU-20A, Shimadzu, Kyoto, Japan) equipped with a column InertSustain (4.6 mm $\times$ $250 \mathrm{~mm}$, Shimadzu, Kyoto, Japan) was used for identification and quantification of the monosaccharide composition in EPS-A, The mobile phase was $80 \%$ ammonium acetate solution and $20 \%$ acetonitrile at a flow rate of $1.0 \mathrm{~mL} / \mathrm{min}$, and the column temperature was at $30^{\circ} \mathrm{C}$. The EPS-A was detected by UV detector at $245 \mathrm{~nm}[27,41]$.

\subsection{Ultraviolet (UV)-Visible and FT-IR Spectroscopy}

A UV-2450 spectrophotometer (Shimadzu, Kyoto, Japan) was used to record the ultraviolet-visible spectrum of EPS-A. A Fourier-transform-infrared spectrophotometer (PerkinElmer, Norwalk, CT, USA) was used to record FT-IR spectra of the samples [42]. 


\subsection{Sewage Flocculation Analysis of EPS-A}

The sewage in this study was collected from the sewage treatment station at Qilu University of technology; $0.2 \mathrm{~g}$ EPS-A was added to $100 \mathrm{~mL}$ of sewage in the $250 \mathrm{~mL}$ flask. The mixture was left to stand for $1 \mathrm{~h}$. Absorbance was measured with a spectrophotometer at $550 \mathrm{~nm}$. The original sewage photogenic liquid absorbance $\mathrm{D}_{\gamma}$ value was illustrated by the $\mathrm{A} 1$, the processed wastewater photogenic liquid absorbance $\mathrm{D}_{\gamma}$ value was illustrated by B1. The flocculation effect is in the flocculating rate:

$$
\text { Flocculating rate }(\%)=(\mathrm{A} 1-\mathrm{B} 1) / \mathrm{A} 1 \times 100 \%
$$

\subsection{Hygroscopic Activity of EPS-A}

Flasks containing 0.1g EPS-A was placed in the sealed dryers with saturated $\mathrm{NaCl}$ or $\mathrm{CaCl}_{2}$ solution, respectively. The relative humidity in the two dryers is $73 \%$ and $32 \%$ respectively. After the preset time, the sample was weighted and hygroscopic rate was calculated. Chitosan and sodium hyaluronate were used as controls. The hygroscopic rate was calculated based on:

$$
\text { Hygroscopic rate }(\%)=(\text { increased weight } / \text { original weight }) \times 100 \%
$$

\subsection{Moisture Retention Determination of EPS- $A$}

Flasks containing $0.1 \mathrm{~g}$ EPS-A with $0.5 \mathrm{~g}$ of distilled water were incubated in the sealed dryers with a saturated $\mathrm{CaCl}_{2}$ solution or silica gel, respectively. The relative humidity in the two dryers is $32 \%$ and $0 \%$. After the preset time, the sample was weighted and hygroscopic rate was calculated. Chitosan and sodium hyaluronate were used as controls. Moisture retention was calculated based on:

Moisture retention $(\%)=($ weight of water after incubation/original weight of water $) \times 100 \%$

\subsection{OH• Free Radical Scavenging Activity}

The free radical scavenging activity of $\mathrm{OH} \bullet$ was analyzed using Fenton's reaction [43]. The hydroxyl radical was generated in a mixture of $1.0 \mathrm{~mL} 1,10$-phenanthroline $(5 \mathrm{mM}), 1.0 \mathrm{~mL}$ sodium phosphate buffer $(0.05 \mathrm{M}, \mathrm{pH} 7.4), 0.5 \mathrm{~mL} \mathrm{FeSO}_{4}(7.5 \mathrm{mM})$ and $0.5 \mathrm{~mL} \mathrm{H}_{2} \mathrm{O}_{2}(3 \%, v / v)$. A series of concentrations of EPS-A were added to the solution and reacted at $37^{\circ} \mathrm{C}$ for $30 \mathrm{~min}$. The absorbance was recorded at $510 \mathrm{~nm}$. $\mathrm{H}_{2} \mathrm{O}$ and Vitamin $\mathrm{C}(\mathrm{Vc})$ were used as the blank and positive control, respectively. Clearance calculation formula was:

$$
\text { Clearance rate }(\%)=\left[\mathrm{A}_{0}-\left(\mathrm{A}_{\mathrm{x}}-\mathrm{A}_{\mathrm{x} 0}\right)\right] / \mathrm{A}_{0} \times 100 \%
$$

where $\Delta \mathrm{A}_{0}$ and $\Delta \mathrm{A}$ denote the absorbance of the blank solution and the absorbance of the solution after addition of the EPS, respectively. $\mathrm{A}_{\mathrm{x} 0}$ was the absorption of the background of the polysaccharide solution.

\subsection{1. $\mathrm{O}_{2} \bullet-$ Free Radicals Scavenging Activity}

The in vitro $\mathrm{O}_{2} \bullet^{-}$-scavenging activity of EPS-A was measured using the pyrogallol method [44]. Briefly, Reagents were added into a cuvette in the following order: $10 \mu \mathrm{L}$ pyrogallol $(3 \mathrm{mM}), 80 \mu \mathrm{L}$ $\mathrm{NaOH}(4 \mathrm{mM}), 10 \mu \mathrm{L}$ EPS-A, and $900 \mu \mathrm{L}$ luminol (with a concentration of $0.1 \mathrm{mM}$ in sodium carbonate buffer, $\mathrm{pH}=10.2$ ) and incubated in a water bath at $25^{\circ} \mathrm{C}$. A series of reactions with a final different concentration of EPS-A were set up and absorbance was recorded at $325 \mathrm{~nm}$. Vc group was treated as control. The clearance calculation formula was:

$$
\text { Clearance rate }(\%)=\left(\Delta \mathrm{A}_{0}-\Delta \mathrm{A}\right) /\left(\Delta \mathrm{A}_{0}\right) \times 100 \%
$$


where $\Delta \mathrm{A}_{0}$ and $\Delta \mathrm{A}$ denote the self-oxidation rate and the self-oxidation rate after adding EPS-A, respectively.

\subsection{Safety Assessment of EPS-A}

Acute oral toxicity of the EPS-A was analyzed following both the Good Laboratory Practice Standards manual and the Organization for Economic Cooperation and Development (OECD) Guidelines for Acute Toxicity of Chemicals no. 420 as previous reported [31]. KM (Kunming) female mice ( 8 weeks old, weight between 19 and $21 \mathrm{~g}$ ) were obtained from the Experimental Animal Center of Shandong University (Jinan, China). All of the experimental protocols were approved by the Experimental Animal Ethic Committee of Qilu University of Technology, Shandong, China (Animal Experimental Ethical Inspection Protocol No. 201605004, 16 May 2016).

\section{Conclusions}

In this study, an exopolysaccharide from Aerococcus uriaeequi (EPS-A) was purified with the number average molecular mass of E $2.22 \times 10^{5} \mathrm{~g} / \mathrm{mol}$ and the weight average molecular mass of $2.84 \times 10^{5} \mathrm{~g} / \mathrm{mol}$. EPS-A was mainly composed of glucose and mannose with $\beta$-configurations. EPS-A showed wastewater flocculation with $79.90 \%$ activity. The sugar can also scavenge hydroxyl free radical in a clear dose-effect relationship. When the EPS-A concentration reached $100 \mu \mathrm{g} / \mathrm{mL}$, the clearance rate reached $45.65 \%$ to $\bullet \mathrm{OH}$. When the concentration was $250 \mu \mathrm{g} / \mathrm{mL}$, the clearance rate reached $67.31 \%$ to $\mathrm{O}_{2}{ }^{-} \bullet$. Finally, EPS-A also showed moisture-absorption and retention properties that can be compared with sodium hyaluronate and chitosan.

Author Contributions: L.H. conceived of the study. C.W. performed the experimental work on EPS-A purification and its biochemical characterization and wrote the manuscript, Q.F., X.Z., and X.L. were responsible for the flocculation test and the hygroscopicity and moisture retention studies, Y.X., W.Z., J.Z. and W.H. analyzed the data. All authors read and approved the final manuscript.

Funding: This work was financially supported by the National Natural Science Foundation of China (31640088), the Natural Science Foundation of Shandong Province (ZR2012CM019, ZR2016CB03, ZR2017BC070), the Shandong Province Science and Technology Project (GG201703060082) and the Doctoral cooperation fund of Shandong Academy of Sciences (2017BSHZ007).

Conflicts of Interest: The authors declare no conflict of interest.

\section{Abbreviations}

$\begin{array}{ll}\text { EPS } & \text { exopolysaccharide } \\ \text { EPS-A } & \text { exopolysaccharide from Aerococcus uriaeequi } \\ \text { FT-IR } & \text { Fourier-transform-infrared spectrometry } \\ \text { HPGFC } & \text { high performance gel permeation chromatography }\end{array}$

\section{References}

1. Helm, R.F.; Huang, Z.; Edwards, D.; Leeson, H.; Peery, W.; Potts, M. Structural characterization of the released polysaccharide of desiccation-tolerant Nostoc commune DRH-1. J. Bacteriol. 2000, 182, 974-982. [CrossRef] [PubMed]

2. Liu, S.B.; Chen, X.L.; He, H.L.; Zhang, X.Y.; Xie, B.B.; Yu, Y.; Chen, B.; Zhou, B.C.; Zhang, Y.Z. Structure and ecological roles of a novel exopolysaccharide from the arctic sea ice bacterium Pseudoalteromonas sp. Strain SM20310. Appl. Environ. Microbiol. 2013, 79, 224-230. [CrossRef] [PubMed]

3. He, J.; Zhang, A.; Ru, Q.; Dong, D.; Sun, P. Structural characterization of a water-soluble polysaccharide from the fruiting bodies of Agaricus bisporus. Int. J. Mol. Sci. 2014, 15, 787-797. [CrossRef] [PubMed]

4. Kim, S.K.; Ravichandran, Y.D.; Khan, S.B.; Kim, Y.T. Prospective of the cosmeceuticals derived from marine organisms. Biotechnol. Bioprocess Eng. 2008, 13, 511-523. [CrossRef]

5. Su, C.A.; Xu, X.Y.; Liu, D.Y.; Wu, M.; Zeng, F.Q.; Zeng, M.Y.; Wei, W.; Jiang, N.; Luo, X. Isolation and characterization of exopolysaccharide with immunomodu-latory activity from fermentation broth of Morchella conica. DARU J. Pharm. Sci. 2013, 21, 5. [CrossRef] [PubMed] 
6. lamas, I.L.; Mata, J.A.; Tallon, R.; Bressollier, P.; Urdaci, M.C.; Quesada, E.; Béjar, V. Characterization of the exopolysaccharide produced by Salipiger mucosus $\mathrm{A} 3(\mathrm{~T})$, a halophilic species belonging to the alphaproteobacteria, isolated on the spanish mediterranean seaboard. Mar. Drugs 2010, 8, 2240-2251. [CrossRef] [PubMed]

7. Liu, R.S.; Li, D.S.; Li, H.M.; Tang, Y.J. Response surface modeling the significance of nitrogen source on the cell growth and Tuber polysaccharides production by submerged cultivation of Chinese truffle Tuber sinense. Process Biochem. 2008, 43, 868-876. [CrossRef]

8. Mancuso Nichols, C.A.; Garon, S.; Bowman, J.P.; Raguenes, G.; Guezennec, J. Production of exopolysaccharides by Antarctic marine bacterial isolates. J. Appl. Microbiol. 2004, 96, 1057-1066. [CrossRef] [PubMed]

9. Nwodo, U.U.; Green, E.; Okoh, A.I. Bacterial exopolysaccharides: Functionality and prospects. Int. J. Mol. Sci. 2012, 13, 14002-14015. [CrossRef] [PubMed]

10. Poli, A.; Anzelmo, G.; Nicolaus, B. Bacterial exopolysaccharides from extreme marine habitats: Production, characterization and biological activities. Mar. Drugs 2010, 8, 1779-1802. [CrossRef] [PubMed]

11. Liang, Z.; Yi, Y.; Guo, Y.; Wang, R.; Hu, Q.; Xiong, X. Chemical Characterization and Antitumor Activities of Polysaccharide Extracted from Ganoderma lucidum. Int. J. Mol. Sci. 2014, 15, 9103-9116. [CrossRef] [PubMed]

12. Shang, N.; Xu, R.; Li, P. Structure characterization of an exopolysaccharide produced by Bifidobacterium animalis RH. Carbohydr. Polym. 2013, 91, 128-134. [CrossRef] [PubMed]

13. Verhoef, R.; Schols, H.A.; Blanco, A.; Siika-Aho, M.; Rättö, M.; Buchert, J.; Lenon, G.; Voragen, A.G.J. Sugar composition and FT-IR analysis of exopolysaccharides produced by microbial isolates from paper mill slime deposits. Biotechnol. Bioeng. 2005, 91, 91-105. [CrossRef] [PubMed]

14. Pereira, L. Identification of phycocolloids by vibrational spectroscopy. In World Seaweed Resources-An Authoritative Reference System; Alan, T., Critchley, M.O., Danilo, B.L., Eds.; ETI Information Services Ltd. Japan international cooperation agency: Yokosuka, Japan, 2006.

15. Pereira, L.; Gheda, F.S.; Ribeiro-Claro, P.J.A. Analysis by vibrational spectroscopy of seaweed polysaccharides with potential use in food, pharmaceutical and cosmetic industries. Int. J. Carbohydr. Chem. 2013, 2013, 537202. [CrossRef]

16. Muthukumar, A.; Baskaralingam, V.; Mani, D.; Sekar, V.; Marimuthu, G.; Naiyf, S.A.; Jamal, M.K.; Mohammed, N.A.; Giovanni, B. Structural characterization of Bacillus licheniformis Dahb1exopolysaccharide-Antimicrobial potential and larvicidal activity on malaria and Zika virus mosquito vectors. Environ. Sci. Pollut. Res. 2018, 25, 18604-18619.

17. Koening, J.L. Vibrational Spectroscopy of Carbohydrates. In Infrared and Raman Spectroscopy of Biological Molecules; Springer International Publishing: Cham, Switzerland, 1979; pp. 125-137.

18. Mathlouthi, M.; Koening, J.L. Vibrational spectra of carbohydrates. Adv. Carbohydr. Chem. Biochem. 1987, 44, 7-89.

19. Wang, Z.; Sheng, J.; Tian, X.; Wu, T.; Liu, W.; Shen, L. Optimization of the production of exopolysaccharides by Bacillus thuringiensis in sand biological soil crusts and its bioflocculant activity. Afr. J. Microbiol. Res. 2011, 5, 2359-2366.

20. Yim, J.H.; Kim, S.J.; Ahn, S.H.; Lee, H.K. Characterization of a novel bioflocculant, p-KG03, from a marine dinoflagellate, Gyrodinium impudicum KG03. Bioresour. Technol. 2007, 98, 361-367. [CrossRef] [PubMed]

21. Roberson, E.B.; Firestone, M.K. Relationship between desiccation and exopolysaccharide production in a soil Pseudomonas sp. Appl. Environ. Microbiol. 1992, 58, 1284-1291. [PubMed]

22. Wu, Q.X.; Lin, D.Q.; Yao, S.J. Design of chitosan and its water soluble derivatives-based drug carriers with polyelectrolyte complexes. Mar. Drugs 2014, 12, 6236-6253. [CrossRef] [PubMed]

23. Bakos, D.; Soldan, M.; Hernandez-Fuentes, I. Hydroxyapatite-collagen-hyaluronic acid composite. Biomaterials 1999, 20, 191-195. [CrossRef]

24. Kodali, V.P.; Sen, R. Antioxidant and free radical scavenging activities of an exopolysaccharide from a probiotic bacterium. Biotechnol. J. 2008, 3, 245-251. [CrossRef] [PubMed]

25. Sun, L.; Wang, C.; Shi, Q.; Ma, C. Preparation of different molecular weight polysaccharides from Porphyridium cruentum and their antioxidant activities. Int. J. Biol. Macromol. 2009, 45, 42-47. [CrossRef] [PubMed] 
26. Asker, M.M.S.; Shawky, B.T. Structural characterization and antioxidant activity of an extracellular polysaccharide isolated from Brevibacterium otitidis BTS 44. Food Chem. 2010, 123, 315-320. [CrossRef]

27. Papageorgiou, S.K.; Kouvelos, E.P.; Favvas, E.P.; Sapalidis, A.A.; Romanos, G.E.; Katsaros, F.K. Metal-carboxylate int eractions in metal-alginate complexes studied with FTIR spectroscopy. Carbohydr. Res. 2010, 345, 469-473. [CrossRef] [PubMed]

28. Patel, A.; Prajapat, J. Food and health applications of exopolysaccharides produced by lactic acid bacteria. Adv. Dairy Res. 2013, 1-8. [CrossRef]

29. Freitas, F.; Alves, V.D.; Reis, M.A. Advances in bacterial exopolysaccharides: From production to biotechnological applications. Trends Biotechnol. 2011, 29, 388-398. [CrossRef] [PubMed]

30. More, T.T.; Yan, S.; John, R.P.; Tyagi, R.D.; Surampalli, R.Y. Biochemical diversity of the bacterial strains and their biopolymer producing capabilities in wastewater sludge. Bioresour. Technol. 2012, 121, 304-311. [CrossRef] [PubMed]

31. Sun, M.L.; Zhao, F.; Shi, M.; Zhang, X.Y.; Zhou, B.C.; Zhang, Y.Z.; Chen, X.L. Characterization and biotechnological potential analysis of a new exopolysaccharide from the arctic marine bacterium Polaribacter sp. SM1127. Sci. Rep. 2015, 5, 18435. [CrossRef] [PubMed]

32. Chen, L.Y.; Du, Y.M.; Wu, H.Q.; Xiao, L. Relationship Between Molecular Structure and Moisture-Retention Ability of Carboxymethyl Chitin and Chitosan. J. Appl. Polym. Sci. 2002, 83, 1233-1241. [CrossRef]

33. Sutherland, I.W. Novel and established applications of microbial polysac-charides. Trends Biotechnol. 1998, 16, 41-46. [CrossRef]

34. El-Zaher, E.H.A.; Mostafa, A.A.; El-Souod, S.M.A.; Enas, M. Optimization and characterization of exopolysaccharides from Pleurotus salmoneo-stramineus and its possible application. Egypt. J. Exp. Biol. (Bot.) 2015, 11, 181-188.

35. Zhang, X.F. The Screen of Polysaccharide-Producing Marine Bacteria and the Study of Its Polysaccharide Fermentation; Shandong Polytechnic University: Jinan, China, 2012.

36. Boyle, C.D.; Reade, A.E. Characterization of two extracellular polysaccharides from marine bacteria. Appl. Environ. Microbiol. 1983, 46, 392-399. [PubMed]

37. Park, S.; Kelley, K.A.; Vinogradov, E.; Solinga, R.; Weidenmaier, C.; Misawa, Y.; Lee, J.C. Characterization of the Structure and Biological Functions of a Capsular Polysaccharide Produced by Staphylococcus saprophyticus. J. Bacteriol. 2010, 192, 4618-4626. [CrossRef] [PubMed]

38. Vincent, P.; Pignet, P.; Talmont, F.; Bozzi, L.; Fournet, B.; Guezennec, J.; Jeanthon, C.; Prieur, D. Production and characterization of an exopolysaccharide excreted by a deep-sea hydrothermal vent bacterium isolated from the polychaete annelid Alvinella pompejana. Appl. Environ. Microbiol. 1994, 60, 4134-4141. [PubMed]

39. Steinmetz, I.; Rohde, M.; Brenneke, B. Purification and characterization of an exopolysaccharide of Burkholderia (Pseudomonas) pseudomallei. Infect. Immun. 1995, 63, 3959-3965. [PubMed]

40. Lv, Y.; Yang, X.B.; Zhao, Y.; Ruan, Y.; Yang, Y.; Wang, Z.Z. Separation and quantification of component monosaccharides of the tea polysaccharides from Gynostemma pentaphyllum by HPLC with indirect UV detection. Food Chem. 2009, 112, 742-746. [CrossRef]

41. Xie, J.Z.; Zou, L.H.; Luo, X.; Qiu, L.; Wei, Q.; Luo, D.; Wu, Y.Q.; Jiao, Y. Structural characterization and immunomodulating activities of a novel polysaccharide from Nervilia fordii. Int. J. Biol. Macromol. 2018, 114, 520-528. [CrossRef] [PubMed]

42. Fan, G.; Tang, C.; Li, Y.; Yang, Y.D.; Zhang, Y. Analysis of Monosaccharide Compositions of Polysaccharides in Coptidis Rhizoma by Pre-column Derivatization HPLC Method. Chin. J. Exp. Tradit. Med. Formulae 2014, $20,74-78$.

43. Chen, Q.; Chen, J.; Du, H.; Li, Q.; Chen, J.; Zhang, G.; Liu, H.; Wang, J. Structural characterization and antioxidant activities of polysaccharides extracted from the pulp of Elaeagnus angustifolia L. Int. J. Mol. Sci. 2014, 15, 11446-11455. [CrossRef] [PubMed]

44. Marklund, S.; Marklund, G. Involvement of the superoxide anion radical in the autoxidation of pyrogallol and a convenient assay for superoxide dismutase. Eur. J. Biochem. 1974, 47, 469-474. [CrossRef] [PubMed]

(C) 2018 by the authors. Licensee MDPI, Basel, Switzerland. This article is an open access article distributed under the terms and conditions of the Creative Commons Attribution (CC BY) license (http:/ / creativecommons.org/licenses/by/4.0/). 